Indonesian Aquaculture Journal, 15 (2), 2020, 85-91

Available online at: http://ejournal-balitbang.kkp.go.id/index.php/iaj

\title{
CONTROL OF Vibrio alginolyticus INFECTION IN ASIAN SEA BASS Lates calcarifer USING AMBON BANANA PLANT POWDER Musa paradisiacal THROUGH THE FEED
}

\author{
Hamida Pattah ${ }^{* \# \#}$, Dinamella Wahjuningrum ${ }^{* *}$, Munti Yuhana**, and Widanarni ${ }^{* *}$ \\ *) Ambon Sea Aquaculture Fisheries Center \\ Jl. Laksdya Leo Wattimena, Waiheru, Baguala, Kota Ambon, Maluku \\ *) Bogor Agricultural University \\ JI. Raya Dramaga Kampus IPB Dramaga Bogor 16680 West Java, Indonesia
}

(Received: December 11, 2019; Final revised: May 4, 2020; Accepted: May 4, 2020)

\begin{abstract}
Asian sea bass is one of economically important commodities in aquaculture. However, its culture often challenged by vibriosis infection which resulted in lower production. The study aimed to evaluate the effectiveness of the ambon banana plant powder application in feed as an effort to control the disease caused by Vibrio alginolyticus infection. Asian sea bass with total length of $7.48 \pm 0.45 \mathrm{~cm}$. Five different treatments were applied in this experiment, i.e. positive control, negative control, prevention, curative, and antibiotic application. The challenge test is carried out on the 15th day. Challenge test was performed with intramuscularly injection of V. alginolyticus at the cell density of $10^{6} \mathrm{CFU} / \mathrm{fish}$. The results showed the amount of feed consumption after the challenge test was highest in the curative and antibiotic control. However, these results were not significantly different $(P>0.05)$ among preventive and curative treatments but were significantly different from controls $(P<0.05)$. Fish treated with supplemented feed showed the highest total erythrocytes, total leukocytes, hemoglobin, respiratory burst, and lysozyme activity compared to controls. IL-1 $\beta$ gene expression increased after the challenge test with the highest level of expression in the curative treatment. It can be concluded that the administration of ambon banana plant powder ( $3 \mathrm{~g} /$ $100 \mathrm{~g}$ diet) could control of $\mathrm{V}$. alginolyticus infection in Asian sea bass and resulted $70.00 \%$ survival rate on prevention and $83.33 \%$ on curative treatments.
\end{abstract}

\section{KEYWORDS: Ambon banana plant powder; Asian sea bass; control; disease; Vibrio alginolyticus}

\section{INTRODUCTION}

Asian sea bass or barramundi (Lates calcarifer) is a commodity with high economic value. In the culture of Asian sea bass, there are several obstacles, one of which is a disease that often occurs in both intensive and extensive fish aquaculture business. One of the most common infectious diseases affecting Asian sea bass is vibriosis (Mohamad et al., 2019). This disease is generally caused by bacteria of the Vibrio genus, i.e. Vibrio alginolyticus which causes a fairly high mortality in the larval stage and seeds.

Control of this disease could to be conducted through prevention and curative methods. Prevention can be made by managing water quality in conditions suitable for the life of Asian sea bass and applying

\# Correspondence: Ambon Sea Aquaculture Fisheries Center. Jl. Laksdya Leo Wattimena, Waiheru, Baguala, Kota Ambon, Maluku, Indonesia.

Tel. + 6282238425161

E-mail: hamidapattah@gmail.com appropriate feed management and low stocking density. Curative actually can be done using antibiotics. However, the use of antibiotics in high doses and in the long term has been banned because it causes the emergence of bacteria that are resistant to antibiotics and produces residues that are harmful to consumers (Cao et al., 2017).

The use of herbal substances is alternative prevention and curative that is environmentally friendly because the herbal substances will be easier to decompose in nature compared to antibiotics (Shakya, 2017). One of the herbal substances that can be used to overcome bacterial diseases is banana plant-based powder.

Ambon banana (M usa paradisiaca) can be used as an antibacterial because it contains alkaloids, saponins, tannins, flavonoids, steroids, glycosides, and terpenoids (Asuquo $\&$ Udobi, 2016). The phytochemical content of herbal substances functions as an antistress, growth accelerator, immunostimulants, and 
antibacterial (Citarasu, 2010). According to research by Ramadhan et al. (2017), $0.5 \mathrm{~g}$ banana stem extract/ $\mathrm{kg}$ feed could increase growth and non-specific immune responses to white spot disease in white shrimp Litopenaeus vannamei.

This research aims to evaluate the effectiveness of the use of ambon banana plant-based powder in feed as an effort to prevent and treat diseases due to V. alginolyticus infection in Asian sea bass (Lates calcarifer).

\section{MATERIALS AND METHODS}

\section{Preparation of Containers and Test Animals}

This research was conducted in March to June 2019 at the Ambon Sea Aquaculture Fisheries Center. The fifteen plastic containers of $42 \mathrm{~cm} \times 61 \mathrm{~cm} \times 33 \mathrm{~cm}$ were used in this experiment. All containers were equipped with aeration and heater to maintain water quality in experimental tank. Before being used, the containers were first cleaned with $30 \mathrm{ppm}$ chlorine and allowed to stand for 24 hours then rinsed with clean water. Test animals were Asian sea bass obtained from the hatchery of the Ambon Sea Aquaculture Fisheries Center. The fish used for this experiment has $7.48 \pm 0.45 \mathrm{~cm}$ total length. The density of fish used in each container was 10 fish. The bacterium for challenge test was Vibrio alginolyticus with a density of $10^{6} \mathrm{CFU} / \mathrm{fish}$.

\section{Test Feed Preparation}

The feed used was commercial feed with 46\%protein content. Banana plant-based powder was mixed with feed by coating method. Ambon banana plant powder at a dose of $3 \mathrm{~g} / 100 \mathrm{~g}$ of feed was mixed with pellets which had been added with $2 \%$ egg white as a binder. The type of antibiotic used was Inrofloxs with a dose of $0.5 \mathrm{~g} / 100 \mathrm{~g}$ of feed. The number of fish per container was 10 fish. Culture of fish used a flowing water system. Fish were fed experimental feed to satiation three times a day: in the morning (8:00), afternoon (12:00), and evening (16:00). Fish blood sampling is carried out on D-1 before challenge test and $D+1, D+3, D+7$ after the challenge test. The experiment was conducted using a completely randomized design (CRD) with five treatments and three replications. The treatment was, positive control $(\mathrm{K}+)$, negative control $(\mathrm{K}-)$, prevention $(\mathrm{PC})$, curative $(\mathrm{Pb})$, and antibiotic control (Ka) (Table 1).

\section{Research Parameters}

The parameters observed included feed consumption (Gabriel, 2019); blood count, included total erythrocytes, total leukocytes (Blaxhall \& Daisley, 1973); and hemoglobin levels (Wedemeyer \& Yasutake, 1977); respiratory burst activity (Anderson \& Siwicki, 1993); lysozyme activity (Ellis, 2011); interleukin-1 $\beta$ gene expression (Buonocore et al., 2005); and survival rates (Biswas et al., 2011).

\section{Data Analysis}

Data on total feed consumption, total erythrocytes, total leukocytes, hemoglobin, phagocytic activity, respiratory bursts, lysozyme activity, and survival rates were tabulated using Microsoft Excel 2016 and analyzed by ANOVA test using SPSS 20 software with a $95 \%$ confidence interval. If the results obtained were significantly different $(P<0.05)$, the process would be followed up by the Duncan test. Meanwhile, data gene expression was analyzed descriptively.

\section{RESULTS AND DISCUSSION}

Before the challenge test, the highest feed consumption was found in prevention treatment and it was significantly different $(P<0.05)$ from the feed consumption in positive control, negative control, antibiotic control, and curative treatments. The feed consumption in all treatments decreased after the antibiotic control treatment (Figure 1).

The highest feed consumption for 14 days (of rearing before the challenge test) was obtained in prevention treatment, and it was significantly different $(P<0.05)$ from the feed consumption in other treatments. This was presumably because the addition of banana plant-based powder in feed could increase of feed consumption. Feed consumption decreased after the challenge test. The decline was possibly because fish stressed due to injections so that their appetite decreased. Appetite of fish infected by bacteria decreased (Zubaidah et al., 2019). Sieira et al. (2018) said that stress on fish could affect appetite, which had an impact on decreasing of feed consumption. After the stress response was gone, the feed consumption increased. This could be seen in the treatments of negative control, curative, prevention, and antibiotics control, whose feed consumptions were higher than feed consumption of fish in positive control treatment. The increase was thought to be because herbal substance that was added to the feed could increase the response of the fish to the feed given. According to Bilen et al. (2019), extracts of Cotinus coggygria and Malva sylvestris in feed could increase the feed consumption in sea bass compared to controls. The scent and taste of herbal substance could increase the feed consumption of fish (Pu et al., 2017).

Observation of blood parameters was carried out on day-1 (D-1) before the challenge test, day-1 (D+1), 
Table 1. Research design

\begin{tabular}{|c|c|c|c|}
\hline \multirow{2}{*}{ Treatments } & \multicolumn{3}{|c|}{ Times } \\
\hline & Day 0 - Day 14 & Day 15 & Day 16 - Day 28 \\
\hline Positive control & Commercial feed & $\begin{array}{l}\text { Challenge test with } \\
\text { V. alginolyticus bacteria }\end{array}$ & Commercial feed \\
\hline Negative control & Commercial feed & $\begin{array}{l}\text { Challenge test with } \\
\text { phosphate buffer saline }\end{array}$ & Commercial feed \\
\hline Prevention & $\begin{array}{l}\text { Banana plant powder } \\
\text { supplemented feed }\end{array}$ & $\begin{array}{l}\text { Challenge test with } \\
\text { V. alginolyticus bacteria }\end{array}$ & Commercial feed \\
\hline Curative & Commercial feed & $\begin{array}{l}\text { Challenge test with } \\
\text { V. alginolyticus bacteria }\end{array}$ & $\begin{array}{l}\text { Banana plant } \\
\text { supplemented feed }\end{array}$ \\
\hline Antibiotic control & Commercial feed & $\begin{array}{l}\text { Challenge test with } \\
\text { V. alginolyticus bacteria }\end{array}$ & Antibiotic feed \\
\hline
\end{tabular}

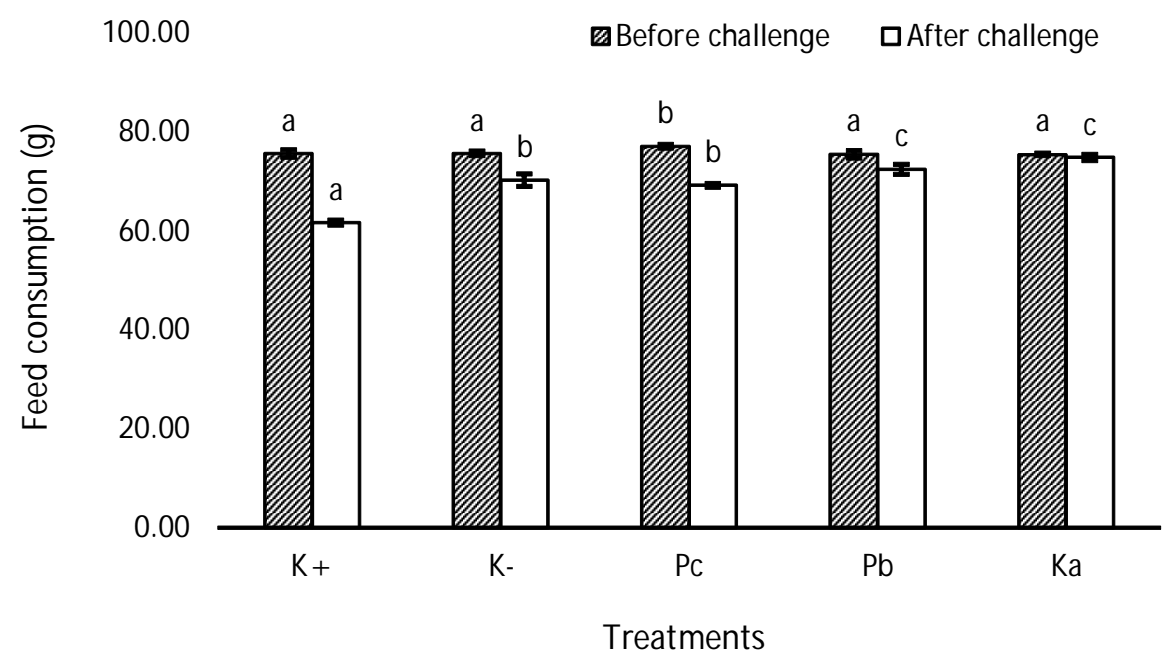

Figure 1. Total feed consumption during the study $(\mathrm{K}+=$ positive control, $\mathrm{K}-=$ negative control, $\mathrm{Pc}=$ prevention, $\mathrm{Pb}=$ curative, $\mathrm{Ka}=$ antibiotic control). Different letters in the same pattern show statistically significant different $(P<0.005)$.

day-3 $(D+3)$, and day-7 $(D+7)$ after the challenge test, included total erythrocytes, total leukocytes, hemoglobin levels, phagocytic activity, respiratory burst, and lysozyme activity (Table 2). That blood parameter could be used to determine the health status of fish.

The number of erythrocytes in all treatments decreased after the challenge test. This was presumably due to the occurrence of lysis of red blood cells by V. alginolyticus so that the number decreased. According to Bunpa et al. (2016), V. alginolyticus can secrete hemolysins, which can lyse red blood cells. However, the decline was still in the normal range. The number of erythrocytes in teleostean fish is 1.05$3 \times 10^{6}$ cells $/ \mathrm{mm}^{3}$ (Irianto, 2005).

Total leukocytes or white blood cells increased after the challenge test. The increase was a self-defense effort due to objects entering the body of the fish. Provision of herbal substance could increase non- specific immune responses of fish so that leukocyte cells increased. This increase indicated that immunostimulants administered had an effect on total leukocytes in the blood, which then had an impact on the activity of phagocytic cells in destroying pathogens that entered the body of fish (Sonida et al., 2014). In addition, the banana plant-based powder contains saponins that can increase the number of white blood cells (Punturee et al., 2005).

Hemoglobin levels in Asian sea bass decreased after the challenge test. The decrease was correlated with the number of red blood cells. Oxygen levels in the blood decreased so that the ability of oxygen to bind blood decreased and affected the condition of fish (Well et al., 2005). Saponins are poisonous to fish, this poisonous compound is antithyroid agent that causes thyroid hormones in the body decrease (Barbosa, 2014). The function of the thyroid hormone 
Table 2. Total erythrocytes, total leukocytes, hemoglobin level, phagocytic activity, respiratory burst, and lysozyme activity on the treatments of $\mathrm{K}+=$ positive control, $\mathrm{K}-=$ negative control, $\mathrm{Pc}=$ prevention, $\mathrm{Pb}=$ curative, $\mathrm{Ka}=$ antibiotic control

\begin{tabular}{|c|c|c|c|c|c|c|}
\hline \multirow{2}{*}{ Parameters } & \multirow{2}{*}{ Times } & \multicolumn{5}{|c|}{ Treatments } \\
\hline & & $\mathbf{K}+$ & K- & Pc & $\mathrm{Pb}$ & Ka \\
\hline \multirow{4}{*}{$\begin{array}{l}\text { Total erythrocytes } \\
\left(\times 10^{6} \mathrm{cell} / \mathrm{mm}^{3}\right)\end{array}$} & D-1 & $1.84 \pm 0.07^{\mathrm{a}}$ & $1.84 \pm 0.15^{\mathrm{a}}$ & $2.36 \pm 0.32^{b}$ & $1.84 \pm 0.07^{\mathrm{a}}$ & $1.84 \pm 0.05^{\mathrm{a}}$ \\
\hline & $D+1$ & $1.65 \pm 0.06^{\mathrm{a}}$ & $1.74 \pm 0.04^{b}$ & $1.86 \pm 0.03^{c}$ & $1.82 \pm 0.02^{C}$ & $1.81 \pm 0.02^{c}$ \\
\hline & $D+3$ & $1.47 \pm 0.04^{\mathrm{a}}$ & $1.71 \pm 0.02^{b}$ & $1.76 \pm 0.01^{c}$ & $1.77 \pm 0.02^{C}$ & $1.75 \pm 0.01^{c}$ \\
\hline & $D+7$ & $1.33 \pm 0.05^{\mathrm{a}}$ & $1.82 \pm 0.01^{b}$ & $1.83 \pm 0.02^{c}$ & $1.87 \pm 0.02^{c}$ & $1.85 \pm 0.01^{c}$ \\
\hline \multirow{4}{*}{$\begin{array}{l}\text { Total leukocytes } \\
\left(\times 10^{5} \text { cell } / \mathrm{mm}^{3}\right)\end{array}$} & D-1 & $3.38 \pm 0.35^{\mathrm{a}}$ & $3.38 \pm 0.38^{\mathrm{a}}$ & $4.30 \pm 0.37^{b}$ & $3.38 \pm 0.22^{\mathrm{a}}$ & $3.38 \pm 0.37^{\mathrm{a}}$ \\
\hline & $D+1$ & $3.53 \pm 0.38^{\mathrm{ab}}$ & $3.18 \pm 0.45^{\mathrm{a}}$ & $4.34 \pm 0.03^{c}$ & $3.84 \pm 0.09^{b c}$ & $3.91 \pm 0.09^{b c}$ \\
\hline & $D+3$ & $3.62 \pm 0.53^{\mathrm{ab}}$ & $3.48 \pm 0.45^{\mathrm{a}}$ & $4.37 \pm 0.09^{c}$ & $4.19 \pm 0.20^{b c}$ & $4.25 \pm 0.14^{b c}$ \\
\hline & $D+7$ & $3.82 \pm 0.28^{b}$ & $3.34 \pm 0.03^{\mathrm{a}}$ & $3.42 \pm 0.32^{\mathrm{ab}}$ & $3.14 \pm 0.07^{\mathrm{a}}$ & $3.27 \pm 0.26^{\mathrm{a}}$ \\
\hline \multirow{4}{*}{$\begin{array}{l}\text { Hemoglobin level } \\
\text { (g/\%) }\end{array}$} & D-1 & $6.13 \pm 0.12^{\mathrm{a}}$ & $6.13 \pm 0.12^{\mathrm{a}}$ & $7.20 \pm 0.20^{b}$ & $6.13 \pm 0.12^{\mathrm{a}}$ & $6.13 \pm 0.12^{\mathrm{a}}$ \\
\hline & $D+1$ & $5.33 \pm 0.12^{\mathrm{a}}$ & $5.53 \pm 0.23^{\mathrm{a}}$ & $6.47 \pm 0.31^{c}$ & $6.07 \pm 0.12^{b}$ & $5.93 \pm 0.12^{b}$ \\
\hline & $D+3$ & $4.93 \pm 0.12^{\mathrm{a}}$ & $5.33 \pm 0.12^{b}$ & $6.20 \pm 0.35^{d}$ & $5.80 \pm 0.20^{c}$ & $5.73 \pm 0.31^{c}$ \\
\hline & $D+7$ & $4.53 \pm 0.12^{\mathrm{a}}$ & $6.47 \pm 0.31^{b}$ & $6.33 \pm 0.31^{b}$ & $6.67 \pm 0.12^{b}$ & $6.53 \pm 0.31^{b}$ \\
\hline \multirow{4}{*}{$\begin{array}{l}\text { Respiratory burst } \\
\text { (OD } 630 \mathrm{~nm})\end{array}$} & D-1 & $0.27 \pm 0.01^{\mathrm{a}}$ & $0.27 \pm 0.04^{\mathrm{a}}$ & $0.35 \pm 0.02^{b}$ & $0.27 \pm 0.02^{\mathrm{a}}$ & $0.27 \pm 0.01^{\mathrm{a}}$ \\
\hline & $D+1$ & $0.35 \pm 0.03^{b}$ & $0.23 \pm 0.04^{\mathrm{a}}$ & $0.44 \pm 0.01^{c}$ & $0.43 \pm 0.01^{c}$ & $0.41 \pm 0.03^{c}$ \\
\hline & $D+3$ & $0.45 \pm 0.03^{b}$ & $0.27 \pm 0.02^{\mathrm{a}}$ & $0.52 \pm 0.02^{c}$ & $0.55 \pm 0.01^{c}$ & $0.54 \pm 0.01^{c}$ \\
\hline & $\mathrm{D}+7$ & $0.42 \pm 0.10^{b}$ & $0.24 \pm 0.03^{\mathrm{a}}$ & $0.37 \pm 0.07^{b}$ & $0.39 \pm 0.01^{b}$ & $0.38 \pm 0.01^{b}$ \\
\hline \multirow{4}{*}{$\begin{array}{l}\text { Lysozyme activity } \\
\text { (IU/mL/minute) }\end{array}$} & D-1 & $26.67 \pm 0.58^{\mathrm{a}}$ & $26.67 \pm 0.58^{a}$ & $31.33 \pm 2.08^{b}$ & $26.67 \pm 0.58^{a}$ & $26.67 \pm 1.53^{a}$ \\
\hline & $D+1$ & $27.33 \pm 1.15^{b}$ & $23.67 \pm 0.58^{a}$ & $36.33 \pm 2.08^{c}$ & $34.33 \pm 1.53^{c}$ & $35.33 \pm 2.52^{c}$ \\
\hline & $D+3$ & $21.67 \pm 2.31^{a}$ & $27.33 \pm 2.08^{b}$ & $34.00 \pm 3.61^{c}$ & $39.33 \pm 2.08^{d}$ & $38.67 \pm 3.51^{c d}$ \\
\hline & $D+7$ & $27.67 \pm 1.15^{b}$ & $23.67 \pm 0.58^{a}$ & $24.33 \pm 0.58^{a}$ & $23.67 \pm 2.08^{a}$ & $23.33 \pm 2.52^{a}$ \\
\hline
\end{tabular}

Note: Different superscript letters in the same line show significantly different treatments effects (Duncan's Test; $P<0.05$ )

is to increase the levels of oxygen that will be used by cells. Oxygen in the body of the fish plays a role in the process of metabolism to produce energy and this energy is used to produce leukocyte cells in large quantities to produce antibodies (Zubaidah et al., 2019).

Respiratory burst activity is directly proportional to phagocytic activity (Rawling et al., 2012). Respiratory burst activity is one indicator to determine the ability of phagocytic cells to eliminate pathogens in the host body by producing reactive oxygen species (ROS) (Abbas et al., 2014). Respiratory burst (RB) activity increased on $D+1$ and $D+3$ after the challenge test. The increase was presumably because high enough exposure so that phagocyte cell activity increased to eliminate bacteria in the body of the fish. On D+7, RB activity decreased. It indicated that the pathogens found in the body of the fish had been eliminated so that there was no death fish on $D+7$.
Lysozyme is one of the mucolytic enzymes that break down $\beta$-1, 4-linked $\mathrm{N}$-acetylmuramic acid, and $\mathrm{N}$-acetylglucosamine, which lyse gram-positive bacteria by the peptidoglycan wall. Lysozyme acts as opsonins, complement activation, and phagocytes to destroy bacteria (Saurabh \& Sahoo, 2008). On D-1, lysozyme activity high in prevention treatment, in which fish was fed with a mixture of banana plantbased powder. This increase was due to the administration of banana plant-based powder that can induce non-specific immune responses such as lysozyme. This is in accordance with the study of Fitrianingrum (2015) on gourami which were fed feeds enriched with additional extracts of banana frond in approved feeds that could increase lysozyme activity. On D+ 1 , lysozyme activity increased in all treatments except in negative control treatment, which actually decreased. The decrease was probably because fish stressed due to injection. Lysozyme activity increased 
on $D+3$ and decreased on $D+7$. However, lysozyme activity in positive control treatment increased. The increased activity of lysozyme was presumably due to the body's ability to fight incoming antigens.

From the data obtained it can be seen that the addition of ambon banana plant powder to preventive treatment and curative can increase the fish immune response compared to the positive control. Ambon banana plant powder can be used as herbal ingredients to control V. alginolyticus infection. Besides being environmentally friendly, banana plant powder is also very economical to apply.

Interleukin-1 $\beta$ gene expression in the anterior kidney of Asian sea bass was observed using the RTqPCR method. The interleukin- $1 \beta$ gene expression of Asian sea bass increased after challenge test with the highest level of gene expression obtained in the curative treatment and the lowest level of gene expression obtained in prevention treatment (Figure 2).

Cytokines are chemicals secreted by immune cells as communication media between cells. Interleukin$1 \beta$ (IL-1 $\beta$ ) cytokine is one of the cytokines that plays a role in the response to microbial invasion, tissue injury, and immunological reactions (Liao et al., 2018). This can be seen in the data obtained in which IL-1 $\beta$ gene expression increased after the challenge test using $V$. alginolyticus, with the highest level of expression found in the medication treatment, compared with before the challenge test (Figure 2). The high level of gene expression was due to herbal substance contained in banana plant-based powder that can activate IL-1 $\beta$ gene expression (Bilen et al., 2019).
In the present study, no dead fish was observed in negative control (K-) treatment. Furthermore, observation of survival rate of Asian sea bass after the challenge test with $\mathrm{V}$. alginolyticus showed that the antibiotic control treatment provided the highest survival rate, but it was not significantly different $(P>0.05)$ from that of the curative treatment. Prevention treatment also shows a higher survival rate compared to positive control treatment (Figure 3).

The death of Asian sea bass began to occur from $D+1$ to $D+6$ after the challenge test. The results showed that the highest survival rate of Asian sea bass was obtained in the antibiotic control treatment compared to positive control. However, the survival rate of the antibiotic control treatment was not significantly different $(P>0.05)$ from that of curative treatment. This happened allegedly because enrofloxacin, vitamin $C$, and vitamin B complex contained in antibiotics can act as immunostimulants. According to Narra et al. (2015), the provision of vitamin $C$ in catfish feed could increase growth and survival. In a study by Bukhari (2018), found the use of banana fronds in eel can increase survival by $90.00 \%$ in prevention treatment and $83.33 \%$ in curative treatment.

\section{CONCLUSION}

Ambon banana plant-based powder ( $3 \mathrm{~g} / 100 \mathrm{~g}$ feed) could increase the immune response and control infectious diseases caused by V. alginolyticus in Asian sea bass (Lates calcarifer). Application of Ambon banana plant-powder supplemental feed through a curative method resulted the best survival of Asian sea bass.

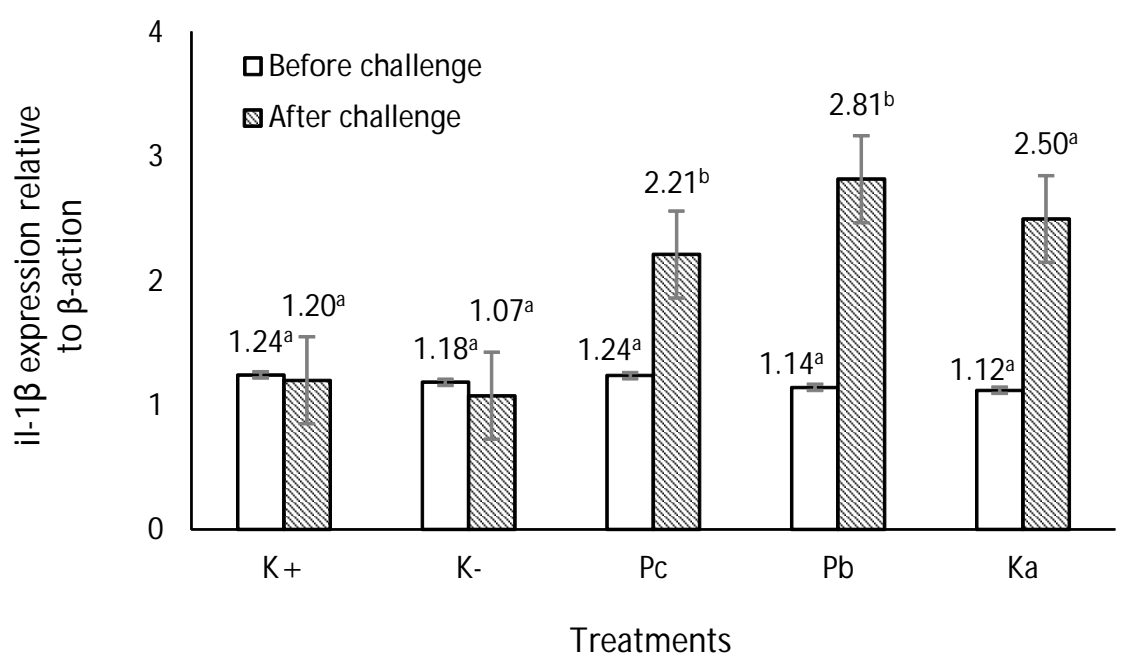

Figure 2. The level of IL-1 $\beta$ gene expression in Asian sea bass (Lates calcarifer) compared with $\beta$-actin before and after the challenge test using $\mathrm{V}$. alginolyticus in positive control $(\mathrm{K}+)$, negative control (K-), prevention $(\mathrm{Pc})$, curative $(\mathrm{Pb})$, and antibiotic control $(\mathrm{Ka})$. 


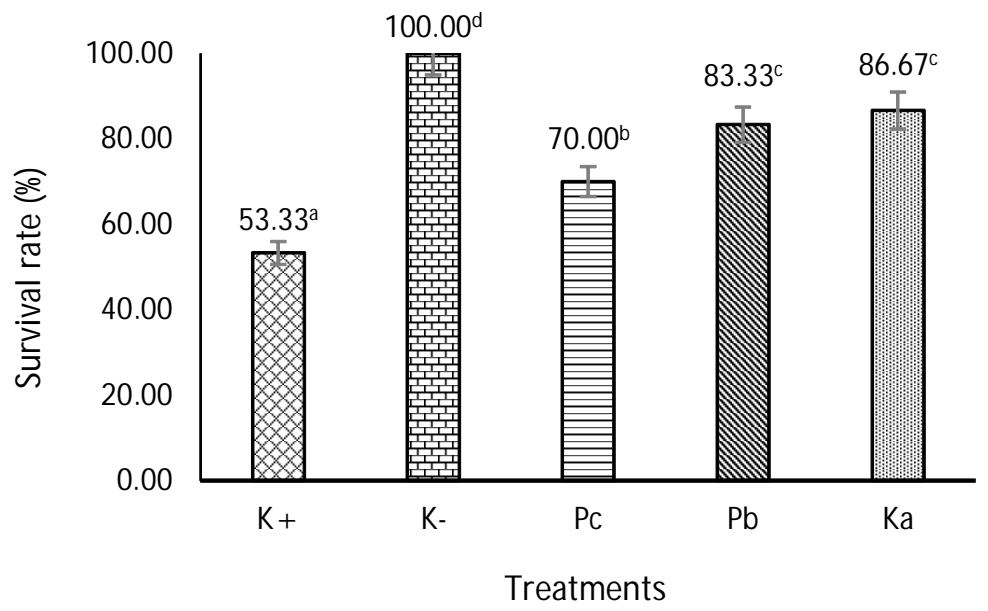

Figure 3. Survival of Asian sea bass after the challenge test with $\mathrm{V}$. alginolyticus in the treatments of $\mathrm{K}+=$ positive control, $\mathrm{K}-=$ negative control, $\mathrm{PC}=$ prevention, $\mathrm{Pb}=$ curative, and $\mathrm{Ka}=$ antibiotic control. Different letters show statistically significant test results $(P<0.05)$.

\section{ACKNOWLEDGEMENT}

I would like to thank the Education Center of the Ministry of Maritime Affairs and Fisheries for funding this research through the 2017 Ministry of Maritime Affairs and Fisheries scholarship grant and Ambon Sea Aquaculture Fisheries Center who have facilitated research in the field.

\section{REFERENCES}

Abbas, A.K., Lichtman, A.H., \& Pillai, S. (2014). Cellular and molecular immunology E-book. Elsevier Health Sciences, p. 1-560.

Anderson, D.P. \& Siwicki, A.K. (1993). Basic hematology and serology for fish health program. Paper presented in second Symposium on Diseases in Asian Aquaculture "Aquatic Animal Health and the Environment". Phuket, Thailand; 25-29th October 1993, $17 \mathrm{pp}$.

Asuquo, E.G. \& Udobi, C.E. (2016). Antibacterial and toxicity studies of the ethanol extract of Musa paradisiaca leaf. Cogent Biology, 2, 1-10.

Barbosa, A,D.P. (2014). An overview on the biological and pharmacological activities of saponins. International Journal of Pharmacology, 6(8), 47-50.

Bilen, S., Sirtiyah, A.M.A., \& Terzi, E. (2019). Therapeutic effects of beard lichen Usnea barbate extract against Lactococcus garvieae in rainbow trout (Oncorhynchus mykiss). Fish \& Shellfish Immunology, 87, 401-409.

Biswas, S.K., Anusua, C., Joysree, D., Sheikh, Z.R., Manik, C.S., \& Utpal, K.K. (2011). Investigation of antibacterial activities of ethanol extracts of Musa paradisiaca Lam. Applied Pharmaceutical Science, 01(06), 133-135.

Blaxhall, P.C. \& Daisley, K.W. (1973). Routine haematological methods for use with fish blood. Fish Biology, 5, 577-581.

Bukhari, M.I. (2018). Control of Aeromonas hydrophila infection in eel fish Anguilla bicolor bicolor using Musa paradisiaca through the feed. Thesis. Bogor Agricultural University, p. 1-21.

Bunpa, S., Semwittayawong, N., \& Vuddhakul, V. (2016). Extracellular enzymes produced by Vibrio alginolyticus isolated from environments and diseased aquatic animals. Procedia Chemistry, 18, 12-17.

Buonocore, F., Forlenza, M., Randelli, E., Benedetti, S., Bossu, P., Meloni, S., Secombes, C.J., Mazzini, M., \& Scapigliati, G. (2005). Biological activity of sea bass (Dicentrarchus labrax L.) recombinant interleukin-1â. Marine Biotechology, 7, 1-10.

Cao, J., Zhang, J., Ma, L., Li, L., Zhang, W., \& Li, J. (2017). Identification of fish source Vibrio alginolyticus and evaluation of its bacterial ghosts vaccine immune effects. Microbiology Open, p. 1-11.

Citarasu, T. (2010). Herbal biomedicines: A new opportunity for aquaculture industry. Aquaculture International, 18, 403-414.

Ellis, R.P., Parry, H., Spicer, Hutchinson, T.H., Pipe, R.K., \& Widdicombe. (2011). Fish and shellfish immunology. Aquaculture, 30, 1209-1222. 
Fitrianingrum, I.D. (2015). Effectivity of banana midrib extract as antibacterial and immune stimulant for giant gourami infected with Aeromonas hydrophila. Thesis. Bogor Agricultural University, p. 1-46.

Gabriel, N.N. (2019). Review on the progress in the role of herbal extracts in tilapia culture. Cogent Food \& Agriculture, 5, 1-21.

Irianto, A. (2005). Teleostei fish pathology. Yogyakarta (ID): Gadjah Mada University Press, p. 1-256.

Liao, C.L., Zhang, G.R., Zhu, D.M., Ji, W., Shi, Z.C., Jiang, R., Fan, Q.X., \& Wei, K.J. (2018). Molecular cloning and expression analysis of interleukin-1 and interleukin 1 receptor type I genes in yellow catfish (Pelteobagrus fulvidraco): Responses to challenge of Edwarsiella ictaluri. Comparative Biochemistry and Physiology, part B, 223, 1-15.

Mohamad, N., Amal, M.N.A., Yasin, I.S.M., Zamri-Saad, M., Nasruddin, N.S., Al-saari, N., Mino, S., \& Sawabe, T. (2019). Vibriosis in cultured marine fishes, a review. Aquaculture, p. 1-82.

Narra, M.R., Rajender, K., Reddy, R.R., Rao, J.V.,\& Begum, G. (2015). The role of vitamin $C$ as antioxidant in protection of biochemical and haematological stress induced by chlorpyrifos in freshwater fish Clariasbatrachus. Chemosphere. 132, 172-178.

Pu, H., Xiaoyu, L., Qingbo, D., Hao, C., \& Yongping, $X$. (2017). Research progress in the application of Chinese herbal medicines in aquaculture: A review. Engineering, 3, 731-737.

Punturee, K., Wild, C.P., Kasinrerk, W., \& Viniketkumnuen, U. (2005). Immunomodulatory activities of Centella asiatica and Rhinacanthus nasutus extracts. Asian Pacific Journal of Cancer Prevention, 6(3), 396-400.

Ramadhan, A., Nuryati, S., Priyoutomo, N.R., \& Alimuddin, A. (2017). Dietary ambonlumut banana stem extract M usa cavendishii var. dwarf Paxton as an immunostimulant for white spot disease prevention in pacific white shrimp Litopenaeus vannamei. Jurnal Akuakultur Indonesia, 16(2), 164-173.

Rawling, M.D., Merrifield, D.L., Snelgrove, D.L., Kuhlwein, H., Adams, A., \& Davies, S.J. (2012). Haemato-immunogical and growth response of mirror carp Cyprinus carpio fed a tropical earthworm meal in experimental diets. Fish \& Shellfish Immunology, 32, 1002-1007.

Saurabh, S. \& Sahoo, P.K. (2008). Lyzozyme: an important defense molecule of fish innate immune system. Aquaculture Research, 39, 223-239.

Shakya, S.R. (2017). Effect of herbs and herbal products feed supplements on growth in fishes, A review. Nepal Journal of Biotechnology, 5(1), 58-63.

Sieira, M.C., Chivite, M., Miguez, J.M., \& Soengas, J.L. (2018). Stress effects on the mechanisms regulating appetite in teleost fish. Frontiers in Endocrinology, 9, 1-9.

Sonida, A., Harpeni, E., \& Tarsim. (2014). Description of the non-specific immune response of white snapper (Lates calcalifer) given black cumin (Nigella sativa) and challenge test with viral nervous necrosis. Aquasains, p. 187-192.

Wedemeyer, G.A. \& Yasutake, W.T. (1977). Clinical methods for the assessement of the effect environmental stress on fish health. Technical Papers of The U.S. Fish and Wildfield Service. US. Depart. of the Interior Fish and Wildlife Service, 89, 1-17.

Well, R.M.G., Baldwin, J., Seymour, R.S., Christina, K., \& Britain, T. (2005). Blood cell function and haematology in two tropical freshwater fishes from Australia. Comparative Biochemistry and Physiology, 141(1), 87-93.

Zubaidah, A., Faidah, K.R., \& Samsundari, S. (2019). Effectiveness of Strychnos ligustrina BI. extract as feed supplementation to increase immune system of nile tilapia (Oreochromis niloticus) wich against Streptococcus agalactiae. Indonesian Journal of Tropical Aquatic, 1(1), 1-8. 